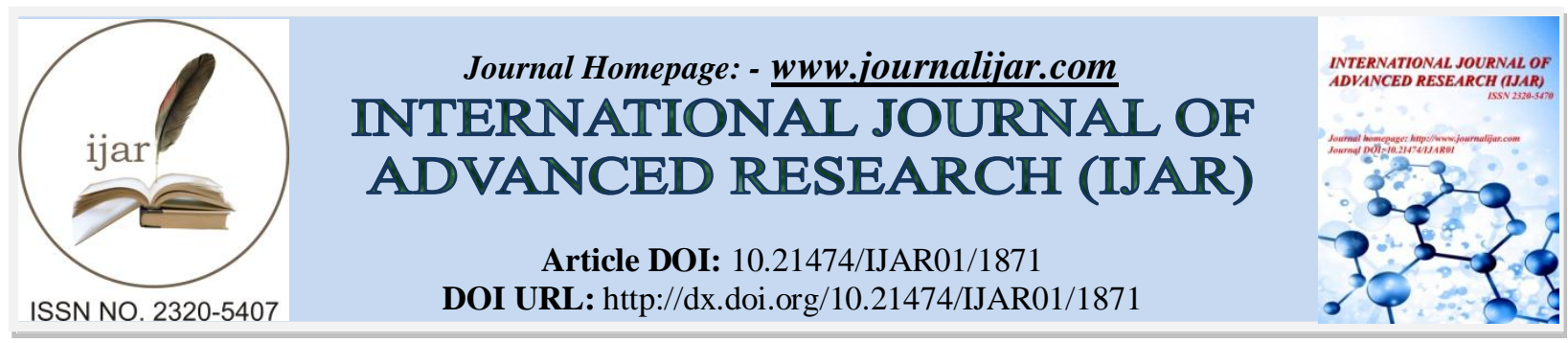

RESEARCH ARTICLE

\title{
TEMPOROMANDIBULAR DISORDER (TMD) IN RELATION TO ORTHODONTIC TREATMENT IN QASSIM REGION OF SAUDI ARABIA.
}

\author{
Dr. Rabia Bilal ${ }^{1}$, Amani Alkhamees ${ }^{2}$ and Nora Alotaibi ${ }^{2}$. \\ 1. Assistant professor:yrtsitneD cirtaideP dna citnodohtrO. \\ 2. Undergraduate dental student at qassim university.
}

\section{Manuscript Info}

Manuscript History

Received: 12 August 2016

Final Accepted: 23 September 2016

Published: October 2016

Key words:-

TMD, TMJ, orthodontictreatment.

\section{Abstract}

Introduction:- TMD is the main cause of pain of non-dental origin in the oro-facial region and is multifactorial in nature. Orthodontic treatment has been linked to TMD since 1980s, which started a series of studies to find out any co-relation between orthodontic treatment and TMD.

Objective:- To determine the prevalence of TMJD in patients during or after fixed orthodontic treatment in Qassim Area.

Materials and Methods:- It was a cross sectional study done on 232 orthodontic patients. Data collection was done by self-administrated questionnaire.

Result:- Data analysis was done by SPSS version 22.Results showed there was no significant co-relation between TMD and orthodontic treatment.

Conclusion:- Orthodontic treatment is not a cause of TMD.

\section{Introduction:-}

TMD is the main cause of pain of non-dental origin in the oro-facial region and is usually defined as a collective term that embraces a number of clinical problems that involve the masticatory muscles ${ }^{(1)}$ The etiology of TMD is multifactorial in nature and is associated with muscle hyperactivity, trauma, emotional stress, malocclusion and other predisposing, precipitating or perpetuating factors of this condition. ${ }^{(2)}$

The need to investigate the relationship between orthodontics and TMD came from the occurrence of legal cases in which patients blamed orthodontists for causing TMD symptoms during or after orthodontic treatment ${ }^{(3)}$. From the late 1980s, the orthodontic community was alerted and gave funds to investigate the relationship between orthodontic treatment and TMD. In 1995, a review of this topic by McNamara, Seligman and Okeson listed eight conclusions that refute this possible association:

1. Signs and symptoms of TMD occur in healthy individuals.

2. Signs and symptoms of TMD increase with age, particularly during adolescence. Thus, TMD that originates during orthodontic treatment may not be related to the treatment.

3. Orthodontic treatment performed during adolescence generally does not increase or decrease the chances of developing TMD later in life.

4. The extraction of teeth as part of an orthodontic treatment plan does not increase the risk of developing TMD.

5. There is no elevated risk for TMD associated with any particular type of orthodontic mechanics.

6. Although a stable occlusion is a reasonable orthodontic treatment goal, not achieving a specific gnathologically ideal occlusion does not result in TMD signs and symptoms. 
7. No method of TM disorder prevention has been demonstrated.

8. When more severe TMD signs and symptoms are present, simple treatments can alleviate them in most patients. (4)

More recent studies concluded that there is no scientific evidence proving that orthodontic treatment will prevent the development of future TMD, or cure an existing disorder. ${ }^{(5)}$

There are not many studies done to co-relate orthodontic treatment and TMD in this part of the world. This study is aimed to determine the prevalence of TMJD in patients during or after fixed orthodontics treatment and identify the inter-relationship between different aspects of orthodontic treatment and TMD in Qassim region of Saudi Arabia.

\section{Materials and Methods:-}

The study proposal and questionnaire were presented to research and ethical committees of Qassim university by November 2015, it got accepted by both committees by December 2015 (code for ethical acceptance \#:EA/18/2015)

The study was a cross sectional study which was done over the period of 5 months from December 2015- April 2016. The data collection was done over the period of 3 months from December 2015- March 2016.

The data was collected from different sources: Qassim university dental clinics (both male and female), different intermediate/secondary schools in different cities in Qassimarea, the $1^{\text {st }}$ high school of Onaizah and $2^{\text {nd }}$ intermediate school in Onaizah.

Inclusion criteria of the study sample consisted of adult and adolescent orthodontic patients with the age range of 13-48 years having all permanent teeth erupted (except $3^{\text {rd }}$ molar). All the subjects were either undergoing or had completed fixed orthodontic treatment for a minimum of 1 year. Subjects who were treated with both extraction and non-extraction treatment modality were included in the study. Subjects who were in mixed dentition were excluded from the study. Also Patients having degenerative lesions of joints including TMJ were excluded from the study.

\section{Study participants:-}

232 participants consisting of 198 females and 34 males participated in the study. All participants had/were having fixed orthodontic treatment ranging from 1 year duration to more than 3 year duration. (Figure I)

Data collection was done by self-administered questionnaire in which subjects were asked about the age, gender, duration of orthodontic treatment and the extractions done before the orthodontic treatment. 13 questions were asked about TMD which were divided into 2 main categories:

1. 8 questions were about the TMD symptoms that were experienced by the patients e.g. (clicking, pain, difficulty in mouth opening).

2. 5 questions about other probable causes of TMD e.g. (trauma, other dental treatment, stress, etc).

The subjects were asked to answer each question twice, once for their experienced symptoms before the orthodontic treatment and the again for during/after the orthodontic treatment.

The sample was divided into 4 groups based on the duration of orthodontic treatment.

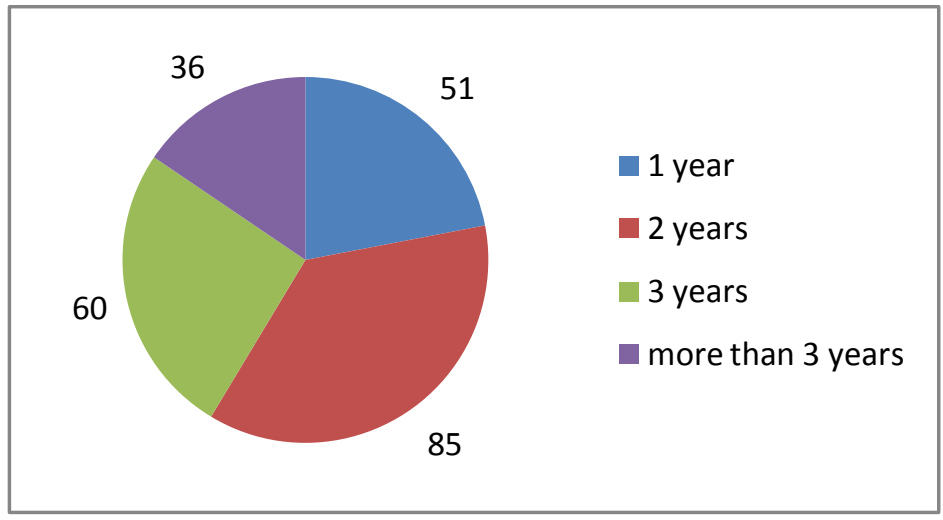

Figure 1:- Duration of orthodontic treatment. 
The data was processed and analyzed through SPSS program (version 22). The descriptive statistics were calculated (mean, SD) by using descriptive analysis. chi-square test was done to determine the significance at level of $0.05 \%$

\section{Result:-}

The results are shown in table 1 with variables in the rows to the left and corresponding frequencies and $\mathrm{p}$ values in the columns to right.

The answers for each variable were divided into 4 categories:

A. Patients who answered with no twice (in both before and after), which indicates no relation to the variable.

B. Subjects who answered with yes twice, which indicates, a pre-existing relation with variable, which didn't change by the orthodontic treatment.

C. Patients who answered with yes before and no after, which indicates pre-existing relation with variable before the orthodontic treatment which was eliminated after the orthodontic treatment.

D. Patients who answered with no before and yes after, which indicated that variable were introduced after the orthodontic treatment.

The frequency for each variable is mentioned for the 4 main groups of the study(figure 1). Finally the $p$ value for the chi square test is mentioned at $0.05 \%$ level of significance. (Significant if $\mathrm{p}<0.05$ ).

Table 1:- Results, showing $\mathrm{P}$ value at $0.05 \%$ level of significance. (Significant if $\mathrm{p}<0.05$ )

\begin{tabular}{|c|c|c|c|c|c|c|c|}
\hline & \multicolumn{5}{|c|}{ Duration of treatment } & \multirow{3}{*}{$\begin{array}{l}\mathbf{P} \\
\text { Value }\end{array}$} \\
\hline & & \multirow{2}{*}{$\begin{array}{c}1 \text { year } \\
\text { Frequency }\end{array}$} & \multirow{2}{*}{$\begin{array}{c}2 \text { years } \\
\text { Frequency }\end{array}$} & \multirow{2}{*}{$\begin{array}{c}3 \text { years } \\
\text { Frequency }\end{array}$} & \multicolumn{2}{|c|}{ More than 3 years } & \\
\hline & & & & & Frequency & & \\
\hline \multirow[t]{4}{*}{ TMJ sounds } & No & 27 & 46 & 34 & 21 & \multirow[t]{4}{*}{0.106} & \multirow[t]{4}{*}{0.106} \\
\hline & $\begin{array}{c}\text { Yes (Before } \\
\& \text { After) }\end{array}$ & 12 & 11 & 11 & 4 & & \\
\hline & $\begin{array}{l}\text { Yes Before } \\
\& \text { No After }\end{array}$ & 3 & 14 & 3 & 0 & & \\
\hline & $\begin{array}{l}\text { No Before } \\
\& \text { Yes After }\end{array}$ & 9 & 14 & 12 & 11 & & \\
\hline \multirow[t]{4}{*}{ TMJ stiffness } & No & 32 & 64 & 44 & 21 & \multirow[t]{4}{*}{0.106} & \multirow[t]{4}{*}{0.106} \\
\hline & $\begin{array}{c}\text { Yes (Before } \\
\& \text { After) }\end{array}$ & 6 & 12 & 1 & 4 & & \\
\hline & $\begin{array}{l}\text { Yes Before } \\
\& \text { No After }\end{array}$ & 3 & 2 & 3 & 2 & & \\
\hline & $\begin{array}{l}\text { No Before } \\
\& \text { Yes After }\end{array}$ & 10 & 7 & 12 & 9 & & \\
\hline \multirow{4}{*}{$\begin{array}{l}\text { Difficulty in } \\
\text { mouth } \\
\text { opening }\end{array}$} & No & 27 & 55 & 36 & 19 & \multirow[t]{4}{*}{0.444} & \multirow[t]{4}{*}{0.444} \\
\hline & $\begin{array}{c}\text { Yes (Before } \\
\& \text { After) }\end{array}$ & 6 & 10 & 4 & 2 & & \\
\hline & $\begin{array}{l}\text { Yes Before } \\
\& \text { No After }\end{array}$ & 5 & 2 & 5 & 5 & & \\
\hline & $\begin{array}{l}\text { No Before } \\
\& \text { Yes After }\end{array}$ & 13 & 18 & 15 & 10 & & \\
\hline \multirow{4}{*}{$\begin{array}{l}\text { Pain when } \\
\text { moving jaw }\end{array}$} & No & 24 & 52 & 39 & 19 & \multirow[t]{4}{*}{ 0.035* } & \multirow[t]{4}{*}{ 0.035* } \\
\hline & $\begin{array}{c}\text { Yes (Before } \\
\& \text { After) }\end{array}$ & 9 & 15 & 1 & 4 & & \\
\hline & $\begin{array}{l}\text { Yes Before } \\
\& \text { No After }\end{array}$ & 8 & 4 & 6 & 2 & & \\
\hline & $\begin{array}{l}\text { No Before } \\
\& \text { Yes After }\end{array}$ & 10 & 14 & 14 & 11 & & \\
\hline \multirow{3}{*}{$\begin{array}{c}\text { Pain while } \\
\text { eating/chewing } \\
\text { food }\end{array}$} & No & 26 & 36 & 31 & 18 & \multirow[t]{3}{*}{0.798} & \multirow[t]{3}{*}{0.798} \\
\hline & $\begin{array}{c}\text { Yes (Before } \\
\& \text { After) }\end{array}$ & 8 & 18 & 6 & 6 & & \\
\hline & Yes Before & 5 & 5 & 6 & 2 & & \\
\hline
\end{tabular}




\begin{tabular}{|c|c|c|c|c|c|c|c|}
\hline & \& No After & & & & & & \\
\hline & $\begin{array}{l}\text { No Before } \\
\& \text { Yes After }\end{array}$ & 12 & 26 & 17 & 10 & & \\
\hline \multirow{4}{*}{$\begin{array}{l}\text { Pain/stiffness in } \\
\text { the neck }\end{array}$} & No & 41 & 65 & 46 & 23 & \multirow[t]{4}{*}{0.830} & \multirow[t]{4}{*}{0.830} \\
\hline & $\begin{array}{l}\text { Yes (Before } \\
\& \text { After) }\end{array}$ & 6 & 11 & 5 & 9 & & \\
\hline & $\begin{array}{l}\text { Yes Before } \\
\& \text { No After }\end{array}$ & 0 & $\S 1$ & 3 & 1 & & \\
\hline & $\begin{array}{l}\text { No Before } \\
\& \text { Yes After }\end{array}$ & 4 & 8 & 6 & 3 & & \\
\hline \multirow{4}{*}{$\begin{array}{l}\text { Received dental } \\
\text { treatment }\end{array}$} & No & 13 & 17 & 7 & 8 & \multirow[t]{4}{*}{0.793} & \multirow[t]{4}{*}{0.793} \\
\hline & $\begin{array}{l}\text { yes (Before } \\
\& \text { After) }\end{array}$ & 16 & 35 & 27 & 13 & & \\
\hline & $\begin{array}{l}\text { Yes Before } \\
\& \text { No After }\end{array}$ & 18 & 26 & 22 & 12 & & \\
\hline & $\begin{array}{l}\text { No Before } \\
\& \text { Yes After }\end{array}$ & 4 & 7 & 4 & 3 & & \\
\hline \multirow[t]{4}{*}{ stress episode } & No & 25 & 47 & 32 & 16 & \multirow[t]{4}{*}{0.566} & \multirow[t]{4}{*}{0.566} \\
\hline & $\begin{array}{l}\text { Yes (Before } \\
\& \text { After) }\end{array}$ & 15 & 23 & 15 & 10 & & \\
\hline & $\begin{array}{l}\text { Yes Before } \\
\& \text { No After }\end{array}$ & 8 & 5 & 5 & 3 & & \\
\hline & $\begin{array}{l}\text { No Before } \\
\& \text { Yes After }\end{array}$ & 3 & 10 & 8 & 7 & & \\
\hline \multirow{4}{*}{$\begin{array}{l}\text { Trauma to the } \\
\text { jaw/TMJ area }\end{array}$} & No & 46 & 73 & 56 & 29 & \multirow[t]{4}{*}{0.421} & \multirow[t]{4}{*}{0.421} \\
\hline & $\begin{array}{c}\text { Yes (Before } \\
\& \text { After) }\end{array}$ & 2 & 1 & 0 & 1 & & \\
\hline & $\begin{array}{l}\text { Yes Before } \\
\& \text { No After }\end{array}$ & 0 & 2 & 2 & 2 & & \\
\hline & $\begin{array}{l}\text { No Before } \\
\& \text { Yes After }\end{array}$ & 3 & 9 & 2 & 4 & & \\
\hline \multirow{4}{*}{$\begin{array}{l}\text { Headache/muscle } \\
\text { stiffness in } \\
\text { morning }\end{array}$} & No & 28 & 49 & 32 & 15 & \multirow[t]{4}{*}{.726} & \multirow[t]{4}{*}{0.726} \\
\hline & $\begin{array}{c}\text { Yes (Before } \\
\& \text { After) }\end{array}$ & 12 & 19 & 11 & 7 & & \\
\hline & $\begin{array}{l}\text { Yes Before } \\
\& \text { No After }\end{array}$ & 3 & 4 & 5 & 3 & & \\
\hline & $\begin{array}{l}\text { No Before } \\
\& \text { Yes After }\end{array}$ & 8 & 13 & 12 & 11 & & \\
\hline
\end{tabular}

\section{Discussion:-}

In the late 1980s the attention of the orthodontic community regarding TMD was awakened following litigation involving orthodontic treatment as the cause of TMD in an orthodontic patient in the US court. The orthodontist at cause lost the case only because at that time there was a lack of evidence based literature in medicine and dentistry. (3)

In 1987 the Board of Trustees of the American Association of Orthodontists (AAO) passed a motion "that the AAO immediately initiate a program to conduct documented studies for the purpose of determining the relationship, or lack thereof, between orthodontic treatment and temporomandibular joint disorders." They also moved to form a new task-oriented committee, the Scientific Studies Committee, to conduct the program. Early in 1988, the committee was formed, consisting of persons with recognized knowledge in this area but with differing backgrounds: a prosthodontist, an oral pathologist, a general practitioner, and two orthodontists. Their conclusion was that orthodontic treatment generally is not a primary factor in TMD. ${ }^{(6)}$ 
This study was undertaken in order to determine the prevalence of TMJD in patients during or after fixed orthodontics treatment and identify the inter-relationship between different aspects of orthodontic treatment and TMD in Qassim region.

After data analysis the major result of this study was that there was no significant difference between orthodontic treatment and TMD. It was also observed that there was no significant difference between duration of orthodontic treatment and TMD.

This result was proved by many other studies in the literature such as :Long - term follow - up study which followed patients until 30 years of age. They identified no link between orthodontic treatment acting as either a preventative measure or a significant cause of TMD. ${ }^{(7)}$

Egermark followed a cohort of patients who had orthodontic care between 1981 and1983 he laudably followed up the patients 20 years later. One of the conclusions was that there was no statistically significant difference in the prevalence of TMD in patients who had received orthodontic treatment when compared with those who hadn't received active orthodontic intervention. ${ }^{(8,9,10)}$

Another major finding was that TMD signs and symptoms (TMJ sounds, TMJ stiffness, pain with mouth opening, pain with chewing) didn't show any statistically significant difference before and after the orthodontic treatment. Also there was no relation between extraction (for the purpose of orthodontic treatment) and TMD.

This finding has been proved constantly by many other researchers such as: A Dibbets\&Van der Weele in 1992 who concluded that after 20 years of observation, it appears that neither orthodontic treatment nor extraction has a causal relationship with the signs and symptoms of TMD. ${ }^{(11)}$

Another longitudinal study done over 20 year investigating the relationship between orthodontic treatment and TMD concluded that orthodontic treatment neither causes nor prevents TMD and that participants with a history of orthodontic treatment did not have higher risk of new or persistent TMD. ${ }^{(14)}$

The only significant result of this study in which the p value was 0.035 was for a single symptom of TMD (pain when moving the jaw to the side), which can't be used alone to identify an etiological factor since it's only one symptom of TMD

A result similar to this (in which a single symptom of TMD increased with orthodontic treatment) was observed by prospective longitudinal study examining adolescent girls undergoing treatment showed that in the treated group there was a significantly reduced prevalence of muscular signs after treatment but that clicking, a symptom often identified, increased in both the treated, untreated, and normal groups over the 2 years of observation. ${ }^{(12,13)}$

In this study no correlation between stress, parafunctional habits or history of trauma and TMD was observed.

On the other hand, a study by Robinand Chiomentowas done in 2010 in which they identified the three most prevalent risk factors for TMD to be, oral parafunctions, traumatic factors, and psychological factors. ${ }^{(15)}$

Another finding was that there was no correlation between TMD and neck/cervical pain. The relation between cervical/neck pain and TMD has been observed by many authors in the literature such as Visscher et al.showed that chronic cranio mandibular pain patients more often suffer from cervical spinal pain than controls. ${ }^{(16)}$ Stiesch-Scholz et al. also reported that patients with raised muscle tenderness of the temporomandibular system exhibited significantly more often pain on pressure of the neck muscles than patients without muscle tenderness of the temporomandibular system. ${ }^{(17)}$ However, Armijo Olivo et al.in a critical review of the literature on this topic, underlined that the association between the cervical spine, the stomatognathic system and craniofacial pain is supported by studies which must be interpreted with caution because of their lack of scientific rigor. This does not exclude a tendency toward a link between cervicalgia and the stomatognathic system. ${ }^{(18)}$

\section{Conclusion:-}

To date, to our knowledge, there has never been a satisfactory evaluation of orthodontics with respect to TMD. There is no evidence that orthodontic treatment treats or prevents temporomandibular disorders (TMDs). There are 
also no trials or studies that reach the threshold required to support the concepts of orthodontic treatment relating to TMD.

It is important to distinguish between absence of evidence and evidence of absence. There may not be evidence of an effect because there are no data regarding the effectiveness of orthodontic treatment for TMD.

\section{Limitation:-}

* A relatively small sample size was used.

* Un-equal female to male ratio that was un-avoidable since the orthodontic treatment is more popular in female patients in Qassim area and the female patients were more willing to participate in the study.

* Age, most of the study subjects were between 16-25 years old which was expected since most orthodontic patients fall in this age range.

\section{Recommendations:-}

* Further research is needed in which a larger sample size is obtained.

* A clinical longitudinal prospective study is advised in which the subjected are monitored before, during and after the orthodontic treatment.

* The use of standardized diagnostic criteria for TMD.

\section{Acknowledgment:-}

* First and for most we would like to thank our supervisor Dr.Rabia Bilal for her help and support.

* We also would like to thank Dr.Ramy Elmoazenfor his help with the data analysis.

\section{References:-}

1. Michelotti A, iodice G. the role of orthodontics in temporomandibular disorders. JOR. 2010:37; 411-29.

2. Machado E, Machado P, Cunali PA, Grehs RA. Orthodontics as risk factor for temporomandibulardisorders: a systematic review. Dental Press J Orthod.2010;15:1-10.

3. Pollack B. Cases of note. Michigan jury awards SAR3,188,822 on ortho case: a tempest in a teapot. Am J Orthod Dentofacial Orthop. 1988; 94:358-60.

4. McNamara JA Jr, Seligman DA, Okeson JP. Occlusion, orthodontic treatment, and temporomandibular disorders: a review. J Orofac Pain. 1995 ;9:73-90.

5. TomislavBadel, MiljenkoMarotti and IvanaSavićPavičin. Temporomandibular Disorders and Orthodontic Treatment - A Review with a Reported Clinical Case, Orthodontics - Basic Aspects and Clinical Considerations, Prof. FaridBourzgui (Ed.), InTech, DOI: 10.5772/31316.

6. Behrents RG, White RA. TMJ research: responsibility and risk. Am J OrthodDentofacialOrthop. 1992 Jan;101:1-3.

7. Mohlin B.O, Derweduwen K, Pilley R et al. Malocclusion and temporomandibular disorder:a comparison of adolescents with moderate to severe dysfunction with those without signs and symptoms of temporomandibular disorder and their further development to 30 years of age .The Angle Orthodontist $2004 ; 74: 319-27$.

8. Egermark I, ThilanderB. Craniomandibular disorders with special reference to orthodontic treatment: an evaluation from childhood to adulthood . American Journal of Orthod and DentofacOrthop. 1992;101:28 - 34 .

9. Egermark I, Magnusson T, Carlsson G.E. A 20 - year follow - up of signs and symptoms of temporomandibular disorders and malocclusions in subjects with and without orthodontic treatment in childhood . The Angle Orthodontist. 2003; 73:109-15 .

10. EgermarkI, Carlsson G.E,Magnusson T. A prospective long - term study of signs andsymptoms of temporomandibular disorders inpatients who received orthodontic treatment in childhood. The Angle Orthodontist. 2005; 75:64 -50.

11. Dibbets JM, Van der Weele LT. Long- term effects of orthodontic treatment, including extraction, on signs and symptoms attributed to CMD. Eur J Orthod.1992; 14:16-20.

12. Henrikson T, Nilner M, KurolJ. Symptoms and signs of temporomandibular disorders before, during and after orthodontic treatment. Swedish Dental Journal. 1999; 23:193 - 207.

13. Henrikson T,Nilner M,Kurol J. Signs of temporomandibular disorders in girls receiving orthodontic treatment. A prospective and longitudinal comparison with untreated Class II malocclusions and normal occlusion subjects .EurJOrthod. 2000;22: 271-81. 
14. Macfarlane T, Kenealy P, Kingdon A, Mohlin B, Pilley R, Richmond S et al. Twenty-year cohort study of health gain from orthodontic treatment: temporomandibular disorders. AmJOrthodDentofacialOrthop. 2009; 135: $1-8$

15. Robin O, Chiomento A. Prevalence of risk factors for temporomandibular disorders: a retrospective survey from 300 consecutive patients seeking care for TMD in a French dental School. J. Stomat. Occ. Med. 2010; 3: 17986.

16. Visscher CM, Lobbezoo F, De Boer W, Van Der Zaag J, Naeije M. Prevalence of cervical spinal pain in craniomandibular pain patients. Eur J Oral Sci 2001; 109:76-80.

17. Stiesch-Scholz M, FinkM, Tschernitschek H. Comorbidity of internalderangement of the temporomandibular joint and silent dysfunctionof the cervical spine. J Oral Rehabil 2003; 30:386-91.

18. Armijo Olivo SA, Magee DJ, Parfitt M, Major PW, Thie NMR. Theassociation between the cervical spine, the stomatognathic system and craniofacial pain: a critical review. J Orofac Pain 2006; 20:271-87. 